\author{
Viktoriya Vakhovska, \\ doktor nauk humanistycznych w zakresie pedagogiki \\ Katedry Języków Obcych, \\ Poleskiego Narodowego Uniwersytetu, \\ Żytomierskie Miejskie Humanistyczne Gimnazjum nr 23 \\ wiktoriawachowska17@gmail.com \\ Daria Vakhovska, \\ Uniwersytet Jagielloński, Wydział Polonistyki, JPwKS \\ d.vakhovska@gmail.com
}

Akademia Ignatianum w Krakowie, Instytut Neofilologii, Filologia Angielska

\title{
WIELOKULTUROWOŚĆ I WIELOJĘZYCZNOŚĆ JAKO MODEL ŻYCIA SPOLECZEŃSTWA WIELOKULTUROWEGO
}

Pojęcie wielokulturowości jest rozumiane z perspektywy pojęcia multiculturalismu - modelu życia społeczeństwa wielokulturowego. Jednym z głównych wymiarów i zarazem komponentów zróżnicowania kulturowego jest wielojęzyczność. Wielokulturowość $i$ wielojęzyczność sa pojęciami wzajemnie powiązanymi, w których język stuży narzędziem do ,uprawiana kultury przez różne narody".

Celem naszej pracy było rozpoznanie $w$ świetle literatury koncepcji wielokulturowości $i$ wielojęzyczności oraz ich realizację we wspótczesnym systemie oświaty.

$W$ trakcie przygotowania niniejszego tekstu metoda wiodaca stała się analiza systemowa badanych pojęć. W aspektach instytucjonalno-prawnych metoda uzupetniajaca stała się analiza dokumentów, która znalazła swoja recepcję przy analizie podstaw prawnych, określajacych kierunki realizacji polityki językowej w społeczeństwach wielokulturowych.

Opracowując podstawy teoretyczne korzystałyśmy z dorobku teoretyczno-praktycznego, niżej zostana wymienione te pozycje, które stały się idea przewodnia tego opracowania: M. Barwiński, M. Byram, M. Barrett. J. Ipgrave, R. Jackson, M. Carmen, M.. Garcia., D. L. Everett,, M. Gruchoła, G. Janusz, W. Martyniuk, A. Sadowski, A. Seretny, E. Lipińska. Ponadto dokonano analizy podstaw prawnych, określajacych kierunki realizacji polityki językowej w społeczeństwach wielokulturowych.

Wyrazy kluczowe: kultura, mniejszości narodowe, wielokulturowość, wielojęzyczność, dwujęzyczność, kompetencje wielokulturowe.

\section{Вікторія Ваховська, Дарія Ваховська. Мультикультуралізм і багатомовність як модель життя в полікультурному суспільстві}

Концепція мультикультуралізму стала моделлю життя в сучасному полікультурному суспільстві. На основі аналізу концепції мультикультуралізму можна зробити висновок, щзо іï розуміють як ідею, нову соціальну модель та політичну доктрину, у якій постулюється рівність культур в етнічно, культурно та релігійно різноманітних суспільствах. Одним з

основних вимірів та складових культурного різноманіття є багатомовність, яку слід розглядати як атрибут особистості людини, котра знає або вивчає мови.

Мультикультуралізм і багатомовність - взаємопов'язані поняття, у яких мова служить «інструментом» для культивування культури різними народами. У мовній та культурній

освіті найбільш поширена концепція Бирама, у котрій використовується термін міжккултурна комунікативна компетенція, вона представляє модель для визначення мети вивчення та оцінки іноземної мови. Підходи, згадані в концепції доповнюють Свропейську

систему опису мовної освіти (CEFR) та формують освітню діяльність, пов 'язану з викладанням та вивченням іноземних мов. Мета нашої роботи - дослідити концепції мултикультуралізму й багатомовності та проаналізувати їх використання в сучасній системі освіти. 
Основним методом дослідження став системний аналіз термінів. В інституційному та правовому аспектах доповнюючим методом був аналіз правових документів, які визначають напрямки реалізації мовної політики в полікультурних суспільствах. Основою нашого дослідження стали теоретичні та практичні напрачювання таких науковців, як

M. Барвінський, М. Байрам, М. Барретm, J. Ipgrave, R. Jackson, M. Carmen, D. L. Everett, M. Gruchola, G. Janusz, W. Martyniuk, A. Sadowski, A. Seretny, E. Lipińska. Ключові слова: культура, національні меншини, полікультуралізм, багатомовність, двомовність, полікультурні компетениії.

\section{Viktoriya Vakhovska, Daria Vakhovska. Multiculturalism and multilingualism as a model of life in a multicultural society}

The concept of multiculturalism is understood from the perspective of multiculturalism, i.e. a model of life in a multicultural society. Based on the analysis of the concept of multiculturalism, it can be concluded that it is understood as an idea, a new social model and a political doctrine in

which the equality of cultures is postulated in ethnically, culturally and religiously diverse societies. One of the main dimensions and components of cultural diversity is multilingualism. Multilingualism should be considered as an attribute of the personality of a person who knows or learns languages. Multiculturalism and multilingualism are interrelated concepts where language serves as a tool for the ,cultivation of culture by different nations." The aim of this paper is to examine the concepts of multiculturalism and multilingualism and to analyze the integration of multicultural and multilingual into the contemporary education system.

The main research method of the paper is a systemic analysis of the analyzed terms. In the institutional and legal aspects, the complementary method is the analysis of the legal documents, defining the directions of the language policy implementation in multicultural societies. During the preparation of this article the leading method became the system analysis of analyzed terms. In the institutional and legal aspects, as the complementary method we used the analysis of document which has found its reception in the analysis of the legal bases which defined the directions of language policy implementation in multicultural societies.

While developing the theoretical foundations, we used the theoretical and practical achievements, the following items will be listed below which became the leading idea of this study: M. Barwinski, M. Byram, M. Barrett, J Ipgrave, R. Jackson, M. Carmen, M Garcia., D. L. Everett,

M. Gruchola, G. Janusz, W. Martyniuk, A. Sadowski, A. Seretny, E. Lipińska.

Keywords: culture, national minorities, multiculturalism, multilingualism, bilingualism, multicultural competences.

Wprowadzenie. Spotkanie z «Innym» - przedstawicielem innej kultury i narodowości jest zawsze wyjątkowym przeżyciem - «wydarzeniem przypadkowym, nie wiadomo kiedy, gdzie i dlaczego. Gdy jednak nastąpi, okazuje się, że było przygotowane przez całą przeszłość osób, które się spotkały» [23, s. 37]. Wartości kulturowe każdego narodu są inne i te różnice wynikają z odmiennych koncepcji w spojrzeniu na naturę człowieka, na sens jego życia.

Kultura, wywiedziona $\mathrm{z}$ oryginalnego znaczenia tego słowa, jako zbioru znaczeń wspólnie „uprawianych” przez daną społeczność, najczęściej kojarzy się z praktykami, poglądami, wartościami, symbolami, tradycjami oraz sposobami życia i rozumienia świata. M. Gruchoła zaznacza, że «kultura stanowi przedmiot zainteresowań kilku dyscyplin. Zajmuje się nią antropologia, etnografia, filozofia, kulturoznawstwo i socjologia». Każda z nich nieco inaczej określa obszar kultury będący przedmiotem jej dociekań, dlatego istnieje wiele definicji kultury, od lapidarnych: «charakterystyczny styl życia danego ludu, sposób na życie», do enumeracyjnych: «całość obejmująca wiedzę», wierzenia, sztukę, moralność, prawo, zwyczaje i inne umiejętności nabywane przez człowieka jako członka społeczeństwa» [8, s. 274-278]. Jedne akcentują to co dziedziczone, a inne to co nowe. Jedne mówią wyłącznie o procesach i czynnościach związanych z pracą lub $\mathrm{z}$ czasem wolnym od pracy, inne natomiast uwzględniają to jedyne, co stanowi sumę 
wytworów przekazywanych $\mathrm{z}$ pokolenia na pokolenie. Definicje socjologiczne łączą kilka wspólnych elementów - kultura jest cechą społeczeństwa, a nie jednostki.

Na podstawie analizy pojęcia wielokulturowości, można stwierdzić, że jest ona rozumiana jako idea, nowy model społeczny i doktryna polityczna, w których postuluje się równorzędność kultur w społeczeństwach zróżnicowanych etnicznie, kulturowo, religijnie, ich wzajemne przenikanie się z równoczesną ochroną odrębności. Koncepcja ta narodziła się w latach 70. i 80. XX wieku w państwach imigranckich, takich jak Kanada, Szwecja, Stany Zjednoczone Ameryki, Australia, Nowa Zelandia, Wielka Brytania i Holandia. Po raz pierwszy została oficjalnie przyjęta jako model życia społecznego w $1971 \mathrm{r}$. w Kanadzie. To pojęcie nawiązuje do angielskiego słowa multiculturalism, które oznacza zróżnicowanie kulturowe danego społeczeństwa oraz opiera się na uznaniu, że zasada dobrobytu i godności człowieka może być realizowana w różny sposób, może wskazywać na:

- prowadzoną politykę władz/rządzących - jest traktowana jako przeciwdziałanie napięciom społecznym, związanym ze zróżnicowaniem społeczno-kulturowym;

- działania środowisk, np. mniejszościowych, skierowane na emancypację i udział różnych środowisk w życiu społeczeństwa, które współtworzą.

Można zatem dostrzec w nim dopełniające się wymiary:

1. Empiryczny - stwierdzenia istnienia zróżnicowania kulturowego w danej społeczności.

2. Mentalny - świadomość społeczna oparta na wzajemnym szacunku dla różnic kulturowych i ich aprobacie.

3. Polityczny - zarządzanie zróżnicowaniem kulturowym, przy założeniu poszanowaniu różnic kulturowych i uznaniu ich reprezentantów [27, s. 32-38].

Koncepcja wielokulturowości jako modelu życia społecznego znalazła swoje miejsce także w polityce Unii Europejskiej. W dzisiejszych czasach, mimo że spotykamy się z różnorodnością ze wszystkich stron, nie zawsze mamy czas, żeby się zastanowić, jak na nas oddziałują spotkania $\mathrm{z}$ ludźmi, którzy pochodzą $\mathrm{z}$ innego kraju. Uważa się, że wielokulturowość to zdolność doświadczania inności kulturowej i wykorzystywania tak nabytych doświadczeń do:

- refleksji nad zagadnieniami, które we własnej kulturze i środowisku zazwyczaj są traktowane jako oczywistość;

- oceny własnych wzorców postrzegania, myślenia, odczuwania i zachowania tak, aby osiągnąć pełniejszą samowiedzę i pogłębione zrozumienie samego siebie.

Zazwyczaj za społeczeństwo wielokulturowe uważa się społeczeństwo zróżnicowane kulturowo na skutek napływu osób urodzonych lub wychowanych w innych kulturach [1, s. 5-6]. Osoby te wnoszą do swojego nowego środowiska życiowego elementy własnego dziedzictwa kulturowego. M. Barwiński określa społeczeństwo wielokulturowe jako współistnienie na danym obszarze społeczności o różnych kulturach oraz odmiennych systemach wartości: pochodzeniu, tradycjach, obyczajach, religiach, językach [2, s. 137]. Czasami o takich społeczeństwach mówi się, że «są mozaiką różnych grup kulturowych, które żyją obok siebie, choć zarazem osobno». Jednak zdaniem A. Sadowskiego samo współwystępowanie na określonej przestrzeni dwóch lub więcej grup, kategorii kulturowych nie oznacza istnienia wielokulturowości. Aby mogło ono zaistnieć, powinny zostać wprowadzone elementarne zasady tolerancji kulturowej. Zdaniem autora $\mathrm{z}$ fenomenem wielokulturowości mamy do czynienia dopiero wówczas, gdy dochodzi do trwałych, wielopłaszczyznowych i dobrowolnych kontaktów międzykulturowych, które powodują wytworzenie się całości jakościowo nowej i kulturowo zróżnicowanej [19, s. 69-82].

Rozważając zagadnienia świadomości wielokulturowej nie sposób pominąć kwestii stereotypów. Stereotypy to pewny rodzaj informacji, zawierający charakterystyczne cechy oceniające i stronnicze, pojmowane przez pryzmaty poznawczy, emocjonalny i behawioralny. Są one utrwalone przez tradycję i trudno podlegają zmianom, a w szczególności odrzuceniu. Stereotypizacja jest pewnym uproszczonym przeświadczeniem, które może dotyczyć różnych zjawisk, a szczególnie grup społecznych. Poglądy stereotypowe mogą prowadzić jednak do uprzedzeń, a te z kolei do dyskryminacji lub stygmatyzacji [30, s. 75-76]. W czasach współczesnych, wielość kultur, tradycji 
stała się «faktem tak bardzo bliskim, codziennym, jak nigdy dotąd. I dlatego jednym z wyzwań współczesności jest kształtowanie osobowości wielokulturowej, a więc wyzwolonej z uprzedzeń i stereotypów». Wypowiadając się na temat różnych kultur należy pamiętać, że nie można krytykować czy oceniać zwyczajów i tradycji i tradycji innych narodów. Jadąc na dłużej do nieznanego, nawet niezbyt odległego miejsca na świecie można doświadczyć tzw. szoku kulturowego (cultural shock). To sytuacja konfrontacji z mieszkańcami odwiedzanego kraju podczas nawiązywania kontaktu i wzajemnego poznawania, wynikająca często z nieznajomości samego kraju, innej kultury, zwyczajów czy gestów. Podobnie osobom, przyjeżdżającym z innego kraju, niektóre zwyczaje mogą wydać się śmieszne, czy nawet niedopuszczalne, dlatego należy pamiętać o unikaniu uprzedzeń i stereotypów i nie szufladkować przedstawicieli innych kultur.

Wielokulturowość broni praw mniejszości narodowych. Współczesna encyklopedia PWN określa mniejszości jako «społeczności trwale zamieszkujące pewne terytorium (zwłaszcza państwa), różniące się od większości jego mieszkańców lub od społeczności panującej politycznie cechą lub cechami, które powodują uznawanie ich w świadomości społecznej za odmienne, a w stosunkach społecznych wywołują nieraz dyskryminację; cechami takimi bywają zwłaszcza: religia, język, świadomość narodowa, kultura» [25]. Współcześnie nie ma powszechnie uznawanej w stosunkach międzynarodowych definicji mniejszości. Taki stan rzeczy spowodowany jest tym, że $\mathrm{w}$ odróżnieniu od obywatelstwa, które jest jednoznacznie określane przez prawo - narodowość jest stanem świadomości każdego człowieka i wynikającą z tego stanu jego identyfikacją z daną grupą etniczną. Współcześnie w Europie wyróżnić można systemy związane zarówno z ochroną praw człowieka, jak i mniejszości oraz mających wpływ na szeroko rozumiany status prawny mniejszości, które umieszczono w Rezolucji Parlamentu Europejskiego z dnia 13 listopada 2018 r. w sprawie norm minimalnych dla mniejszości w UE [18]. Ustawa o mniejszościach narodowych i etnicznych oraz o języku regionalnym pozwala stwierdzić, że zapewnia osobom należącym do mniejszości możliwości «korzystania z praw obywatelskich i traktowania mniejszości nie z punktu zagrożenia interesów państwa, ale jako łącznika w stosunkach międzynarodowych, reguluje sprawy związane $\mathrm{z}$ rozwojem języka regionalnego osób, należących do mniejszości narodowych i etnicznych, a także sposób realizacji zasady równego traktowania osób bez względu na pochodzenie etniczne» [10].

Główną podstawą istnienia Unii Europejskiej jest wspólna przynależność różnych narodów, oparta na różnorodności językowej i kulturowej. W 1992 roku w ramach Rady Europy w celu ochrony oraz promocji języków regionalnych oraz języków mniejszości narodowych w Europie została zatwierdzona Europejska karta języków regionalnych lub mniejszościowych - europejska konwencja (CETS 148). W dniu 12 maja 2003 r. Rzeczpospolita Polska podpisała Europejską kartę języków regionalnych lub mniejszościowych, a w 2009 r. Karta została ratyfikowana [6]. Zgodnie z jej założeniami «języki regionalne lub mniejszościowe» oznaczają języki, które: «są tradycyjnie używane na określonym terytorium państwa przez obywateli tego państwa tworzących grupę mniejszą liczebnie od pozostałej części ludności tego państwa, różnią się od oficjalnego języka (języków) tego państwa, nie obejmuje to ani dialektów oficjalnego języka (języków) tego państwa, ani języków migrantów. «Terytorium, na którym używany jest język regionalny lub mniejszościowy» oznacza obszar geograficzny, na którym wspomniany język jest środkiem komunikowania się takiej liczby ludzi, która uzasadnia przyjęcie różnych środków ochronnych i wspierających, przewidzianych w niniejszej karcie «Języki nieterytorialne» oznaczają języki używane przez obywateli danego państwa, które różnią się od języka lub języków stosowanych przez pozostałą część ludności tego państwa, które jednak, chociaż są tradycyjnie używane na terytorium tego państwa, nie mogą być identyfikowane $\mathrm{z}$ określonym jego obszarem.

Wspólną wartością, którą należy chronić i kultywować, jest różnorodność języków i kultur europejskich. Stąd też konieczne jest pokonanie bariery komunikacyjnej pomiędzy członkami poszczególnych wspólnot tak, aby ta różnorodność stała się przyczynkiem do wzbogacania repertuaru językowego i kulturowego jednostki. Propozycja nowego podejścia w dydaktyce języków obcych powstał w wyniku wieloletniej współpracy specjalistów z różnych krajów pod 
przewodnictwem Rady Europy to ESOKJ (nazywany w skrócie Systemem opisu lub po prostu Opisem). Europejski system opisu kształcenia językowego stanowi podstawę służącą do opracowania programów języków nowożytnych, egzaminów, podręczników, pełny opis tego, co uczący się powinien opanować, kompetencji pozwalającą na mierzenie wyników uczenia się na każdym poziomie nauki języka obcego [7].

Wielojęzyczność należy postrzegać jako atrybut jednostki i to takiej, która uczy się języków obcych, to nawet przy przyjęciu takiego założenia może ona przybierać rożne formy. Jeszcze pewien czas temu przyjmowano, że termin ten oznacza znajomość wszystkich tych języków na poziomie swojego języka ojczystego. Dziś eksperci nie są tak ortodoksyjni i do grona tego włączają również osoby znające języki obce na niższym poziomie lub dopiero się ich uczące [5, s. 5-6]. Wielojęzyczność w leksykonie pedagogiki oraz psychologii definiowana jest następująco: «wielojęzyczność oznacza dla jednostki fakt, iż posługuje się ona kilkoma językami używanymi w różnych kontekstach życia, przy czym języki nie muszą być opanowane na tym samym poziomie we wszystkich umiejętnościach językowych (takich jak słuchanie, mówienie, czytanie czy pisanie)» [13, s. 257-267]. W polszczyźnie termin wielojęzyczność jest niejednoznaczny, obejmuje różne aspekty tego zjawiska. Z jednej strony wielojęzyczność oznacza znajomość kilku języków. Z drugiej zaś - może dotyczyć obszaru, na którym występuje równolegle wiele języków. Trzecim ujęciem, typowym także dla Unii Europejskiej, jest pojmowanie wielojęzyczności jako polityki, zgodnie z którą od organizacji, przedsiębiorstwa lub instytucji wymaga się stosowania więcej niż jednego języka do celów komunikacji wewnętrznej lub zewnętrzne. Wielojęzyczność może być wynikiem zróżnicowanej oferty językowej systemu oświaty, innych instytucji, zachęcających do nauki języków obcych. Wielojęzyczność można zdefiniować jako znajomość i używanie kilku języków przez jednostkę lub społeczność językową na określonym obszarze geograficznym.

Bardzo ważnym uzupełnieniem pojęcia wielojęzyczności jest pojęcie różnojęzyczności, które jest używane w dokumentach określających cele i zasady europejskiej polityki językowej w Europejskim Systemie Opisu Kształcenia Językowego. «Różni się ono od pojęcia wielojęzyczności, określającego znajomość kilku języków przez indywidualnego człowieka lub współistnienie różnych języków używanych przez daną społeczność. <..> Pojęcie różnojęzyczności sięga dalej, wskazując na fakt, że kolejne doświadczenia językowe i kulturowe <... nie są gromadzone $\mathrm{w}$ postaci odrębnych modułów, lecz składają się one na jedną całościową kompetencję komunikacyjną, w której wszystkie te doświadczenia i języki wzajemnie się przenikają i na siebie wpływają» [7]. Da się tutaj więc zauważyć związek pojęcia różnojęzyczności z wprowadzonym przez Cooka (pojęciem kompetencji wielojęzycznej (ang. multicompetence), rozumianej jako współobecność różnych języków w umyśle człowieka. Niezależnie od konkretnego terminu, który jest używany, różnojęzyczność jest poszerzeniem pojęcia wielojęzyczności.

W. Martyniuk zaznacza, że w obrębie kompetencji różnojęzycznej i różnokulturowej umiejętności posługiwania się poszczególnymi językami zazwyczaj nie znajdują się na jednym poziomie, lecz są zróżnicowane na jeden lub więcej ze sposobów:

- ogólnie głębsza znajomość jednego języka w porównaniu z innymi;

- inny profil kompetencji w jednym języku w porównywaniu z innymi;

- różnice profilów różnokulturowego i różnojęzycznego [16, s. 122-123].

W kategoriach wielojęzyczności jest ujmowane zjawisko dwujęzyczności. Analizując literaturę przedmiotu można stwierdzić, że nie istnieje jednej ogólnej definicji lub modelu dwujęzyczności. Naukowcy rozpatrują jako pewne kontinuum obejmujące zarówno tych, którzy od urodzenia w sposób naturalny poznają język ojczysty/obcy lub tych, którzy zaczęli uczyć się języka ojczystego/obcego. E. Lipińska zaznacza, że «dwujęzyczność polega na umiejętności posługiwania się wszystkimi sprawnościami w języku ojczystym i drugim oraz na częstym używaniu obydwu języków w różnych sytuacjach i z różnymi uczestnikami aktu komunikacji» [27, s. 24]. A. Martowicz, dokonuje jej podziału na: dwujęzyczność symultaniczną/równoczesną (kiedy dziecko przyswaja dwa języki od urodzenia lub przed ukończeniem trzeciego roku życia) i sukcesywną/sekwencyjną (kiedy przyswajanie drugiego języka rozpoczyna się po trzecim roku 
życia). Rozróżnia się ponadto jeszcze dwujęzyczność: czynną (rozumienie i zdolność mówienia w dwóch językach) i bierną (zdolności rozumienia drugiego języka bez zdolności posługiwania się nim) $[14$, s. 6].

Zdaniem Daniel L. Everetta «język jest zakodowany w naszych genach i istnieje w każdym z nas jako wrodzony i instynktowny byt» [29]. D. L. Everett odwołuje się do antropologii, prymatologii, informatyki, filozofii, językoznawstwa, psychologii oraz własnych pionierskich badań nad amazońskim plemieniem Pirahã i w sposób bezprecedensowy objaśnia naturę języka jako zjawiska kształtowanego przez społeczeństwo. Przedstawia dzięki temu nowy sposób widzenia tego jak myślimy i kim jesteśmy. Przez słowa uczymy się spostrzegać świat i każdy z nas został wychowywany w różnych unikalnych kulturach, które poszerzają naszą percepcję wszystkiego co nas otacza. Język formuje nasz «językowy obraz świata», w którym odzwierciedlają się kognitywne zdolności każdego. Proces dorastania w pewnym językowym środowisku świadczy o przybraniu kultury tego kraju, bo język nie tylko determinuje sposób postrzegania świata, a także kształtuje kulturę społeczności, w którym wychowujemy się i myślimy od dzieciństwa. twierdzi, że: «każdy naród ma własny rezerwuar myśli, które się stały znakami, tym rezerwuarem jest jego język: jest to rezerwuar, do którego wnosiły swój wkład stulecia - jest to skarbiec myśli całego narodu» [1, s. 264]. Język jest pewnym systemem znaków, który kultywujemy i jeśli chcemy poznać kulturę jakiegoś kraju - najlepszy sposób nauczyć się języka tego kraju. Wtedy doświadczamy tę kulturę na własny sposób i widzimy różnice lingwistyczne, które rozwijają nasz umysł i zdolności. Rodzimi użytkownicy kształtują język. Z drugiej strony, ponieważ język jest ściśle związany z kulturą kraju, osoby uczące się nowego języka zmieniają sposób myślenia, dlatego ucząc się innego języka «jesteśmy coraz bardziej świadomi tego, że podstawą nauczania i uczenia się języka jest jego potencjał do kształtowania, tworzenia i przekazywania znaczenia. Używając słów Austina, możemy powiedzieć, że istnieje wiele różnych sposobów działania słowami - nazywamy je językami» [15, s. 9-14].

Związek nauczania języka obcego z nauczaniem kultury tego języka nie zawsze był rzeczą oczywistą i znacznie ewoluował na przestrzeni lat. Autorzy ESOKJ stwierdzają, że różnojęzyczność jest postrzegana $\mathrm{W}$ kontekście różnokulturowości. <..> «Poszczególne składniki, tworzące kompetencję kulturową danego człowieka (kultura narodowa, regionalna, grupowa) i wynikające z jego indywidualnych doświadczeń, nie istnieją odrębnie ani oddzielnie obok siebie - przeciwnie, wzajemnie na siebie wpływają, są stale na nowo porównywane i sobie przeciwstawiane, kształtując w efekcie jego jednostkową kompetencję różnokulturową. Jej istotną częścią składową jest kompetencja różnojęzyczna, wchodząca także w związki z pozostałymi składnikami kompetencji różnokulturowej człowieka» [7, s. 17]. Dlatego znajomość elementów kulturowych jest zawsze obecna w modelach kompetencji komunikacyjnej.

W odniesieniu do edukacji językowej i kulturowej najbardziej rozpowszechniona jest jednak koncepcja Byrama, który używa terminu interkulturowa kompetencja komunikacyjna i przedstawia model mający być punktem wyjścia dla wyznaczenia celów nauczania, uczenia się i oceniania języka obcego. Ten model interkulturowej kompetencji komunikacyjnej, który uwzględnia następujące czynniki: postawy, które są warunkiem koniecznym dla skutecznej komunikacji interkulturowej; chodzi tutaj o ciekawość świata i otwartość na inne kultury, gotowość niewyrażania pochopnych opinii i sądów na temat innych kultur, a także chęć dokonywania porównań i krytycznego spojrzenia na własne zachowania i przekonania; wiedza na temat norm kulturowych obowiązujących we własnym kraju, jak i w kraju, z którego pochodzi rozmówca, oraz procesów interakcyjnych na poziomie indywidualnym i społecznym; umiejętności, które pozwalają na skuteczne działanie $w$ różnych okolicznościach $i$ są związane $z$ interpretowaniem $i$ dokonywaniem porównań (np. w odniesieniu do pewnych zjawisk, zachowań czy wytworów kultury), jak również z odkrywaniem i wchodzeniem w interakcje (np. rozwijanie świadomości istnienia pewnych różnic $\mathrm{w}$ zachowaniach w wyniku rozmów z przedstawicielami innej kultury) [3, s. 15-30]. 
Wymienione w koncepcji podejścia są zbliżone do System Opisu Pluralistycznych Podejść do Języków i Kultur (FREPA) The Framework of Reference for Pluralistic Approaches to Languages and Cultures. Są one uzupełnieniem Europejskiego Systemu Opisu Kształcenia Językowego (ESOKJ) i wspierają działania związane z nauczaniem i uczeniem się kilku języków jednocześnie. Zgodnie $\mathrm{z}$ definicją opracowaną $\mathrm{w}$ ramach projektu FREPA, termin podejścia pluralistyczne do języków i kultur «ma stanowić przyczynek do popularyzacji edukacji różnojęzycznej i międzykulturowej». System Opisu Pluralistycznych Podejść do Języków i Kultur (FREPA Kompetencje i zasoby) oraz narzędzia, które zostały opracowane na jego podstawie, opisują i ułatwiają nauczanie i uczenie się międzyprzedmiotowe oraz umożliwiają rozwój repertuaru językowego i kulturowego uczniów. Część opisowa, przedstawiająca postawy wobec języków i kultur, może być wykorzystywana do celów nauczania i uczenia się jednego języka obcego, jak również może stanowić przyczynek do nauki wielu języków jednocześnie. W metodyce nauczania języków można wyróżnić cztery podejścia pluralistyczne: otwarcie na języki; interkomprehensja (rozumienie języków pokrewnych); zintegrowane podejścia dydaktyczne do uczenia się wielu języków; podejście międzykulturowe [4, s. 4-5]. Dialog, otwartość wobec Innego jest uwarunkowana pewnymi cechami osobowości, które sprzyjają rozwinięciu umiejętności i kompetencji - rozumianych jako minimalne wymagania do osiągnięcia kompetencji międzykulturowych. Należą do nich:

- Szacunek dla innych (poszanowanie godności innych osób);

- Tożsamość jako samoświadomość jednostki (rozumienie spostrzegania świata przez pryzmat systemu wartości innej osoby);

- Patrzenie z innych perspektyw, poglądów (analiza różnic i podobieństw poglądów innych osób);

- Słuchanie (angażowanie się w autentycznych dialog międzykulturowy);

- Adaptacja (akceptacja innej perspektywy, poglądów innej osoby);

- Budowanie relacji (budowanie trwałych międzykulturowych interakcji, więzi społecznych);

- Pokora kulturowa (łączy szacunek, zdolność utrzymywania postawy interpersonalnej, zorientowanej na aspekty tożsamości kulturowej ważne dla innej osoby) [9].

Od kilku lat Polska jest najpopularniejszym unijnym państwem dla imigrantów, tworzących wspólnotę wielokulturową. Według szacunków GUS wśród cudzoziemców przebywających w Polsce zdecydowanie przeważają obywatele krajów trzecich Armenii, Białorusi, Gruzji, Mołdawii, Rosji i Ukrainy[22]. W 2017 r. rząd przyjął Strategię na rzecz Odpowiedzialnego Rozwoju do roku 2020 (z perspektywą do 2030 r.). Jednym z przewidzianych w SOR projektów strategicznych jest «Polityka migracyjna Polski» [21].

Podsumowanie. Na podstawie powyższych rozważań, można stwierdzić, że zakres realizacji wielokulturowości jako modelu życia społecznego jest tematem ważnym dla współczesnego społeczeństwa. Kapitał ludzki jest najistotniejszym elementem polityki integracji w społeczeństwach wielokulturowych. Każda kultura jest mozaiką wielu innych, które poprzez wspólny dialog i otwartość wobec Innego kształtują nowy model współczesnego życia. W naszym przekonaniu taka zasada jest możliwa poprzez wspieranie rozwoju kompetencji różnojęzycznych i międzykulturowych, rozumianych jako ciągły proces uczenia się, spotykania i komunikowania się z ludźmi $\mathrm{z}$ innych kultur; popularyzacji edukacji różnojęzycznej i międzykulturowej $\mathrm{z}$ wykorzystaniem podejścia pluralistycznego do języków i kultur System Opisu Pluralistycznych Podejść do Języków i Kultur (FREPA); integracji społeczeństwa wielokulturowego poprzez kompleksową politykę migracyjną. Lista podmiotów, które zajmują się obecnie problematyką migracji i integracji jest obszerna. Obejmuje ona zarówno instytucje rządowe, samorządowe, organizacje społeczne, ośrodki naukowe, jak i inicjatywy nieformalne. Miasta polskie stały się laboratorium integracji wielokulturowej $\mathrm{i}$ wielojęzykowej, $\mathrm{w}$ których powstają centra wielokulturowe, będące obecnie główną przestrzenią prowadzenia rozmaitych działań (od projektów kulturalnych, poprzez naukę języków, po punkt przyjmowania wniosków o legalizację pobytu). 


\section{Список використаних джерел та літератури}

1. Anusiewicz J. Problematyka językowego obrazu świata w poglądach niektórych językoznawców i filozofów niemieckich XX wieku. Językowy obraz świata / red. J. Bartmiński. Lublin : Wydawnictwo Uniwersytetu Marii Curie-Skłodowskiej, 1999. S. 261-289.

2. Barwiński M. Wielokulturowość we współczesnych polskich badaniach geograficznych i edukacji geograficznej - zarys problematyki. Przeglad geograficzny. 2016. № 88. S. 137-157.

3. Byram M., Barrett M., Ipgrave J., Jackson R., Carmen M., Garcia M. Autobiografia spotkań międzykulturowych. Warszawa, 2011.33 s.

4. Candelier M., Schröder-Sura A. Wspieranie rozwoju kompetencji różnojęzycznych i międzykulturowych w klasie szkolnej. Języki obce w szkole. 2012. № 4. S. 4-11.

5. Coste D., North B., Sheils J., Trim J. Europejski system opisu kształcenia językowego: uczenie się, nauczanie, ocenianie, thum / red. H. Komorowska. Warszawa, 2003. $272 \mathrm{s.}$

6. Europejska karta języków regionalnych lub mniejszościowych. http://mniejszosci.narodowe.mswia.gov.pl/mne/prawo/europejska-karta-jezyk/europejska-kartajezyk/6777 (дата звернення 30.05.2020).

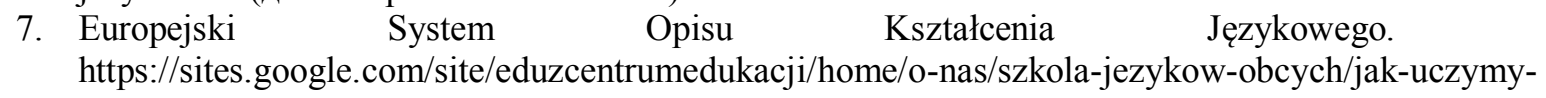
/system-europejski-i-certyfikaty (дата звернення 13.05.2020).

8. Gruchoła M. Kultura w ujęciu socjologicznym. Roczniki Kulturoznawcze. Lublin, 2010. T. 1. S. 95-113.

9. Intercultural Competences: Conceptual and Operational Framework. URL: https://unesdoc.unesco.org/ark:/48223/pf0000219768 (дата звернення 25.05.2020).

10. Internetowy System Aktów Prawnych. Ustawa z dnia 6 stycznia 2005 r. o mniejszościach narodowych $i$ etnicznych oraz o jezzyku regionalnym. Dz.U. 2005. № 17. poz. 141. URL : http://isap.sejm.gov.pl/isap.nsf/DocDetails.xsp?id=wdu20050170141 (дата звернення 28.09.2020).

11. Janusz G. Definiowanie mniejszości w dokumentach międzynarodowych i aktach prawa wewnętrznego. Annales Universitatis Mariae Curie-Sktodowska. Lublin, 2008. T. 15/2. S. 95-123.

12. Językowy obraz świata / red. J. Bartmiński. Lublin : Wydawnictwo Uniwersytetu Marii CurieSkłodowskiej, 1999. $297 \mathrm{~s}$.

13. Karwowska D. Problem wielojęzyczności w niemieckiej literaturze naukowej. Przegląd Pedagogiczny. 2018. № 1. S. 257-267.

14. Martowicz A. Dwujęzyczność w pytaniach i odpowiedziach. Edynburg, 2018. 36 s.

15. Martyniuk W. 50 lat Szkoły Języka i Kultury Polskiej Uniwersytetu Jagiellońskiego w Krakowie: album jubileuszowy / red. J. Mendyk. Kraków, 2019. S. 9-14.

16. Martyniuk W. Europejski system opisu kształcenia językowego a nauczanie języka polskiego jako obcego. Z zagadnień dydaktyki języka polskiego jako obcego / red. E. Lipińska, A. Seretny. Kraków, 2006. S. 329.

17. Mikulska-Jolles A. Kto kształtuje politykę migracyjną i integracyjną w Polsce? Analiza interesariuszy. Warszawa, 2019. URL : https://pl.trenkwalder.com/news/ukraincy-w-polsce-co-stoi-za-ich-sukcesem (дата звернення 02.06.2020).

18. Polityka migracyjna Polski. URL : https://interwencjaprawna.pl/wp-content/uploads/2019/06/Politykamigracyjna-Polski-wersja-ostateczna.pdf (дата звернення 02.06.2020).

19. Rezolucja Parlamentu Europejskiego z dnia 13 listopada 2018 r. w sprawie norm minimalnych dla mniejszości w UE (2018/2036(INI)). URL : https://www.prawo.pl/akty/dz-u-ue-c-2020-36313,69368627.html (дата звернення 30.05.2020).

20. Sadowski A. Optimum. Studia Ekonomiczne. 2016. № 4(82) S. 69-82.

21. Strategia na rzecz Odpowiedzialnego Rozwoju do roku $2020 \mathrm{z}$ perspektywą do 2030. URL: https://www.google.com/.gov.pl (дата звернення 30.05.2020).

22. Szałtys D. Cudzoziemcy na krajowym rynku pracy w ujęciu regionalnym. Raport Końcowy. Centrum Badań $i$ Edukacji Statystycznej GUS. Warszawa, 2018. $56 \mathrm{~s}$. URL : https://stat.gov.pl/files/gfx/portalinformacyjny/pl/defaultstronaopisowa/6149/1/1/cudzoziemcy_na_krajow ym_rynku_pracy_w_ujeciu_regionalnym-raport.pdf (дата звернення 13.05.2020).

23. Szmidt D. T., Mejnartowicz A. Europejska wielokulturowość i wielojęzyczność. Investigationes Linguisticae. Poznań, 2009. T. XVIII. S. 80-88.

24. Tischner J. Fenomenologia spotkania. Analecta Cracoviensia. Kraków, 1978. № 10. S. 73-98.

25. Tomaszewski J. Mniejszości. URL : https://encyklopedia.pwn.pl/haslo/mniejszosci;3942384.html (дата звернення 29.06.2020).

26. Waszczyńska K. Kurs „Prawa i role mniejszośći narodowych i etnicznych” w ramach projektu «Mniejszości aktywne lokalnie». Lekcja 8 Wielokulturowość. Fundacja Edukacja dla Demokracji. 
Warszawa, 2013. URL : https://issuu.com/edudemo/docs/lekcja_8._wielokulturowosc (дата звернення 13.05.2020).

27. Z zagadnień dydaktyki języka polskiego jako obcego / red. E. Lipińska, A. Seretny. Kraków, 2006. 340 s.

28. Zator-Peljan J. Wpływ kultury własnej na postrzeganie innych obszarów kulturowych. Języki Obce w Szkole. 2014. № 1. S. 32-38.

29. Zykubek A. Ewolucja, ewolucja języka, język - narzędzie kultury. URL: https://kognitywistyka.kul.pl/jezyk-narzedzie-kultury-daniel-l-everett/ (дата звернення 13.05.2020).

30. Żuk G. Problematyka językowego obrazu świata w poglądach niektórych językoznawców i filozofów niemieckich XX wieku. Przeobrażenia w języku i komunikacji medialnej na przełomie XX i XXI wieku $/$ red. M. Karwatowska, A. Siwiec. Chełm : Wydawnictwo Drukarnia Best Print, 2010. S. 239-257.

31. Żurek J. Stereotypy mieszkają w języku - rozmowa z prof. Jerzym Bartmińskim (UMCS). Scriptores Scholarum. Lublin, 1998. № 19/20. S. 11-17.

\section{References (translated \& transliterated)}

1. Anusiewicz, J. (1999). Problematyka językowego obrazu świata w poglądach niektórych językoznawców i filozofów niemieckich XX wieku [The issue of the linguistic image of the world in the views of some German linguists and philosophers of the 20th century]. Jezzkowy obraz świata - Linguistic picture of the world. J. Barmiński (Ed.). Lublin: Wydawnictwo Uniwersytetu Marii Curie-Skłodowskiej [in Polish].

2. Barwiński, M. (2016). Wielokulturowość we współczesnych polskich badaniach geograficznych i edukacji geograficznej - zarys problematyki [Multiculturalism in contemporary Polish geographic research and geographic education - an outline of the issue]. Przeglad geograficzny - Przeglad Geograficzny, 88, 137157 [in Polish].

3. Byram, M., Barrett, M., Ipgrave, J., Jackson, R., Carmen, M., \& Garcia, M. (2011). Autobiografia spotkań międzykulturowych [Autobiography of intercultural encounters]. Warsaw [in Polish].

4. Candelier, M., \& Schröder-Sura, A. (2012). Wspieranie rozwoju kompetencji różnojęzycznych i międzykulturowych $\mathrm{w}$ klasie szkolnej [Supporting the development of multilingual and intercultural competences in the classroom]. Języki obce w szkole - Foreign languages at school, 4, 4-11 [in Polish].

5. Coste, D., North, B., Sheils, J., \& Trim, J. (2003). Europejski system opisu ksztatcenia jezzykowego: uczenie sie, nauczanie, ocenianie, thum [The European Framework of Reference for Languages: Learning, Teaching, Assessment, transl]. H. Komorowska (Ed.). Warsaw [in Polish].

6. Europejska karta języków regionalnych lub mniejszościowych [European Charter for Regional or Minority Languages]. (n.d.). mniejszosci.narodowe.mswia.gov.pl. Retrieved from http://mniejszosci.narodowe.mswia.gov.pl/mne/prawo/europejska-karta-jezyk/europejska-kartajezyk/6777 [in Polish].

7. Europejski System Opisu Kształcenia Językowego [European System for the Description of Language Education]. (n.d.). sites.google.com. https://sites.google.com/site/eduzcentrumedukacji/home/o-nas/szkola-jezykow-obcych/jak-uczymy/system-europejski-i-certyfikaty [in Polish].

8. Gruczoła, M. (2010). Kultura w ujęciu socjologicznym [Culture in the sociological approach]. Roczniki Kulturoznawcze - Roczniki Kulturoznawcze (Vol. 1), (pp. 95-113). Lublin [in Polish].

9. Intercultural Competences: Conceptual and Operational Framework [Intercultural Competences: Conceptual and Operational Framework]. (n.d.). unesdoc.unesco.org. Retrieved from https://unesdoc.unesco.org/ark:/48223/pf0000219768 [In French].

10. Internetowy System Aktów Prawnych [Internet System of Legal Acts]. (2005). Ustawa z dnia 6 stycznia 2005 r. o mniejszościach narodowych i etnicznych oraz o języku regionalnym - The Act of 6 January 2005 on National and Ethnic Minorities and Regional Language, 1/141. Retrieved from http://isap.sejm.gov.pl/isap.nsf/DocDetails.xsp?id=wdu20050170141 [in Polish].

11. Janusz, G. (2008). Definiowanie mniejszości w dokumentach międzynarodowych i aktach prawa wewnętrznego [Defining minorities in international documents and acts of internal law]. Annales of Maria Curie-Skłodowska University (Vol. 15/2), (pp. 95-113). Lublin [in Polish].

12. Barmiński, J. (Ed.). (1999). Językowy obraz świata [Linguistic picture of the world]. Lublin: Wydawnictwo Uniwersytetu Marii Curie-Skłodowskiej [in Polish].

13. Karwowska, D. (2018). Problem wielojęzyczności w niemieckiej literaturze naukowej [The problem of multilingualism in German scientific literature]. Przeglad Pedagogiczny - Pedagogical Review, 1, 257267 [in Polish]. 
14. Martowicz, A. (2018). Dwujęzyczność w pytaniach i odpowiedziach [Bilingualism in questions and answers]. Edinburgh [in Scotland].

15. Martyniuk, W. (2019). 50 lat Szkoły Języka i Kultury Polskiej Uniwersytetu Jagiellońskiego w Krakowie: album jubileuszowy [ 50 years of the School of Polish Language and Culture of the Jagiellonian University in Krakow: jubilee album]. J. Mendyk (Ed.). Krakow [in Polish].

16. Martyniuk, W. (2006). Europejski system opisu kształcenia językowego a nauczanie języka polskiego jako obcego [The European System of Language Learning Description and Teaching Polish as a Foreign Language]. Z zagadnien dydaktyki języka polskiego jako obcego - From the issues of didactics of Polish as a foreign language. E. Lipińska, A. Seretny (Eds.). Krakow [in Polish].

17. Mikulska-Jolles, A. (2019). Kto kształtuje politykę migracyjną i integracyjną w Polsce? [Who shapes the migration and integration policy in Poland?]. Analiza interesariuszy - Stakeholder analysis. Warsaw. Retrieved from https://pl.trenkwalder.com/news/ukraincy-w-polsce-co-stoi-za-ich-sukcesem [in Polish].

18. Polityka migracyjna Polski [Poland's migration policy]. (n.d.). interwencjaprawna.pl. Retrieved from https://interwencjaprawna.pl/wp-content/uploads/2019/06/Polityka-migracyjna-Polski-wersjaostateczna.pdf [in Polish].

19. Rezolucja Parlamentu Europejskiego z dnia 13 listopada 2018 r. w sprawie norm minimalnych dla mniejszości w UE (2018/2036(INI)) [European Parliament resolution of 13 November 2018 on minimum standards for minorities in the EU (2018/2036 (INI))]. (2018). www.prawo.pl. Retrieved from https://www.prawo.pl/akty/dz-u-ue-c-2020-363-13,69368627.html [In French].

20. Sadowski, A. (2016). Optimum [Optimum]. Studia Ekonomiczne - Economic Studies, 4/82, 69-82 [in Polish].

21. Strategia na rzecz Odpowiedzialnego Rozwoju do roku 2020 z perspektywą do 2030 [Strategy for Responsible Development until 2020 with a perspective until 2030]. (n.d.). www.google.com/.gov.pl. Retrieved from https://www.google.com/.gov.pl [in Polish].

22. Szałtys, D. (2018). Cudzoziemcy na krajowym rynku pracy w ujęciu regionalnym. Raport Końcowy [Foreigners in the domestic labor market in a regional perspective. Final Report]. Centrum Badan $i$ Edukacji Statystycznej GUS - Statistical Research and Education Center of the Central Statistical Office. Warsaw [in Polish].

23. Szmidt, D. T., \& Mejnartowicz, A. (2009). Europejska wielokulturowość i wielojęzyczność [European multiculturalism and multilingualism]. Investigations in Linguistics (Vol. XVIII), (pp. 80-88). Poznan [in Polish].

24. Tischner, J. (1978). Fenomenologia spotkania [Phenomenology of the meeting]. Analecta Cracoviensia Analecta Cracoviensia, 10, 73-98 [in Polish].

25. Tomaszewski, J. (n.d.). Mniejszości [Minorities]. Retrieved from https://encyklopedia.pwn.pl/haslo/śmieszosci;3942384.html [in Polish].

26. Waszczyńska, K. (2013). Kurs "Prawa i role mniejszośći narodowych i etnicznych" w ramach projektu "Mniejszości aktywne lokalnie". Lekcja 8 Wielokulturowość [Law Course and the roles of national and ethnic minorities "as part of the project" Locally active minorities". Lesson 8 Multiculturalism]. Fundacja Edukacja dla Demokracji - Education for Democracy Foundation. Warsaw. Retrieved from https://issuu.com/edudemo/docs/lekcja_8._wielokulturowosc [in Polish].

27. Lipińska, E., \& Seretny, A. (Eds.). (2006). Z zagadnień dydaktyki języka polskiego jako obcego [From the issues of didactics of Polish as a foreign language]. Krakow [in Polish].

28. Zator-Peljan, J. (2014). Wpływ kultury własnej na postrzeganie innych obszarów kulturowych [The influence of one's own culture on the perception of other cultural areas]. Języki Obce w Szkole - Języki Obce w Szkole, 1, 32-38 [in Polish].

29. Zykubek, A. (n.d.). Ewolucja, ewolucja języka, język - narzędzie kultury [Evolution, language evolution, language - a tool of culture]. Retrieved from https://kognitywistyka.kul.pl/jezyk-narzedzie-kultury-daniell-everett/ [in Polish].

30. Żuk, G. (2010). Problematyka językowego obrazu świata w poglądach niektórych językoznawców i filozofów niemieckich XX wieku [The issue of the linguistic image of the world in the views of some German linguists and philosophers of the 20th century]. Przeobrażenia w języku i komunikacji medialnej na przetomie XX $i$ XXI wieku - Transformations in language and media communication at the turn of the 20th and 21th centuries. M. Karwatowska, \& A. Siwiec (Eds). Chełm [in Polish].

31. Żurek, J. (1998). Stereotypy mieszkają w języku - rozmowa z prof. Jerzym Bartmińskim (UMCS) [Stereotypes live in language - an interview with prof. Jerzy Bartmiński (UMCS)]. Scriptores Scholarum (issue 19/20), (pp. 11-17). Lublin [in Polish].

Статтю отримано $19.10 .2020 \mathrm{p}$.

Прийнято до друку 20.11.2020 p. 